\title{
Potential Role of Protease Nexin-2/Amyloid $\beta$-Protein Precursor as a Cerebral Anticoagulant $^{a}$
}

\author{
WILLIAM E. VAN NOSTRAND, ${ }^{b}$ \\ ALVIN H. SCHMAIER, ${ }^{c}$ AND STEVEN L. WAGNER ${ }^{d}$ \\ ${ }^{b}$ Department of Microbiology and Molecular Genetics \\ University of California \\ Irvine, California 92717 \\ 'Department of Internal Medicine \\ Division of Hematology/Oncology \\ University of Michigan \\ Ann Arbor, Michigan 48109-0724 \\ ${ }^{d}$ Salk Institute Biotechnology/Industrial Assaciates \\ 505 Coast Bouleward South \\ La Jolla, California 92037
}

One of the hallmark fearures of Alzheimer's disease (AD) is deposition of the amyloid $\beta$-protein in extracellular neuritic plaques and within cerebral blood vessel walls. ${ }^{1-5}$ Similar neuropathology is observed in brains of individuals with hereditary cerebral hemorrhage with amyloidosis-Dutch type. ${ }^{6}$ The amyloid $\beta$-protein is an insoluble, selfaggregating peptide with a molecular mass of $4.2 \mathrm{kDa}{ }^{1,4}$ CDNA cloning studies revealed that the amyloid $\beta$-protein is derived from a larger precursor protein, termed the amyloid $\beta$-protein precursor (APP), which is encoded by a gene located on chromosome $21 .^{7-10}$ Subsequent studies showed that APP is translated from at least three alternatively spliced mRNAs resulting in polypeptides of 695,751 and 770 amino acids. ${ }^{11-13}$ The latter two species contain an additional insert which is structurally similar to the inhibitory domain of Kunitz-type serine protease inhibitors (KPI). The secreted form of APP containing the KPI domain has been shown by us and others to be identical to the serine protease inhibitor, protease nexin-2 (PN-2). ${ }^{14,15}$ The identity of APP and PN-2 was demonstrated by amino terminal and additional peptide amino acid sequences of $\mathrm{PN}-2$ aligning with amino acid sequences deduced from cDNAs for APP. Full-length APP is normally cleaved at the carboxy terminal side of Lys $^{16}$ in the amyloid $\beta$-protein domain, resulting in a secreted PN-2 that contains the first fifteen amino acids of the amyloid $\beta$-protein at its carboxy terminus. ${ }^{16-18}$ Currently, little is known about the physiological function(s) of PN-2 and the other APP isoforms. Recent findings suggest a potential physiological role for PN-2/APP as a cerebral anticoagulant.

\footnotetext{
a Supported by the American Health Assistance Foundation (WEVN and AHS) and Grant AG00538 from the National Institute on Aging (WEVN).
} 


\section{PN-2 is the Predominant Isoform of APP in Human Brain}

Studies have demonstrated that mRNA encoding the forms of APP that contain the KPI domain are present in most tissues. ${ }^{11-13,19}$ On the other hand, mRNA encoding the form of APP that lacks the KPI domain is found primarily in brain and has been suggested to be the major isoform of APP mRNA in this tissue. In human brain two major APP proteins have been identified with approximate molecular masses of 120 $\mathrm{kDa}$ and $105 \mathrm{kDa}{ }^{20-22}$ The $120-\mathrm{kDa}$ isoform of APP protein in human brain has been shown to contain the KPI domain based on immunoblotting studies with a polyclonal antiserum raised against a synthetic peptide corresponding to a region of the KPI domain. ${ }^{21}$ The $105-\mathrm{kDa}$ isoform of APP protein did not react with this same antiserum, suggesting that this APP isoform lacks the KPI domain. ${ }^{21}$ The seemingly abundant amount of APP protein that lacks the KPI domain in brain appeared to be consistent with the high levels of its corresponding mRNA in this tissue.

Recently we described a qualitative and quantitative study that analyzed the different APP protein isoforms in human brain. ${ }^{23}$ In addition to immunoblotting analyses, our studies employed functional assays that were specific for KPI-containing isoforms of APP proteins. These assays included formation of sodium dodecyl sulfate polyacrylamide gel electrophoresis (SDS-PAGE) stable complexes with an ${ }^{125}$ I-labeled protease $e^{24-26}$ and precipitation by trypsin-agarose. The immunoblotting and functional assays showed that human fibroblasts and human platelets contained a $120-\mathrm{kDa}$, KPIcontaining form of APP protein. On the other hand, immunoblotting showed that normal and $\mathrm{AD}$ brain contained $120-\mathrm{kDa}$ and $105-\mathrm{kDa}$ forms of APP protein. However, the functional assays indicated that both forms of APP proteins in the brain contained the KPI domain. ${ }^{23}$ Quantitative functional assays indicated that $>80 \%$ of the total APP protein in human brain contains the KPI domain. The findings in this study were extended by functional analyses comparing APP proteins that were purified from brain and cerebrospinal fluid of normals and AD patients. A previous study indicated that $<10 \%$ of the APP proteins in cerebrospinal fluid contain the KPI domain. ${ }^{27}$ Figure 1 shows that APP proteins purified from cerebrospinal fluid formed $<10 \%$ of the amount of SDS-PAGE stable complexes with ${ }^{125}$ I-labeled protease than did APP proteins purified from brain. Similar findings were observed with purified $\mathrm{APP}$ proteins from normals and $\mathrm{AD}$ patients. Together, these KPI-specific functional assays indicate that the majority of APP in human brain contains the KPI domain, regardless of its molecular mass on SDS-polyacrylamide gels.

Recent immunohistochemical and immunoblotting studies by Arai at al. ${ }^{28}$ detected APP proteins in various tissues and cell types of the central nervous system. However, most nonneural tissues were notably devoid of APP immunoreactivity. Extending these findings we have recently conducted quantitative immunoblotting studies to determine the levels of PN-2/APP in a variety of nonhuman primate tissues. These studies showed that PN-2/APP was most abundant in brain with some presence in testis and kidney (unpublished data). It is noteworthy that similar studies showed that protease nexin$1(\mathrm{PN}-1)$, a potent antithrombin, is also found primarily in brain. These studies raise the intriguing question as to why there is a rich and relatively exclusive investment of PN-2/APP, as well as PN-1, in brain.

\section{PN-2/APP Is an Abundant Platelet a Granule Protein and Potent Inhibitor of Coagulation Factor XIa}

Several findings have suggested a vascular contribution of PN-2/APP and the amyloid $\beta$-protein. APP mRNA transcripts have been recognized in human umbilical 



FIGURE 1. Quantitation of KPI-containing isoforms of APP in human brain and cerebrospinal fluid. (A) Equivalent amounts of APP proteins purified from normal brain tissue (lane I), normal cerebrospinal fluid (lane 2), $\mathrm{AD}$ brain tissue (lane 3), and $\mathrm{AD}$ cerebrospinal fluid (lane 4) were incubated with a molar excess of ${ }^{125} \mathrm{I}$.labeled epidermal growth factor binding protein and analyzed by SDS-PAGE with subsequent autoradiography. (B) The high molecular weight complexes between ${ }^{125}$ I-epidermal growth factor binding protein and the KPI-containing isoforms of APP were quantitated by laser scanning densitometry. Purified cerebrospinal fluid APP contains < 10\% the amount of KPI-containing isoforms than purified brain APP. 
vein endothelial cells. ${ }^{29}$ Furthermore, interleukin I, which is elevated in brain tissue from patients with $A D$ and Down's syndrome, upregulates APP mRNA in endothelial cells through protein kinase C. ${ }^{29,30}$ In addition, various sized PN-2/APP proteins between 105 and $135 \mathrm{kDa}$ have been recognized in leptomeningeal and cortical blood vessel walls. ${ }^{31}$ Other vascular sources for PN-2/APP have been sought. The finding that heparinized plasma contained some PN-2/APP immunoreactivity ${ }^{32}$ suggested that circulating cells in blood could be releasing this protein. Our recent studies showed that PN-2/APP circulates in blood as a platelet $a$ granule protein and is secreted upon activation of platelets by physiological agonists. ${ }^{33}$ The presence of platelet PN-2/APP has been confirmed by three other laboratories. ${ }^{34-36}$ When compared with other prominent cells of the intravascular compartment, platelets appear to be a relatively specific, intravascular source for PN-2/APP, accounting for $99 \%$ of its concentration in the intravascular compartment. ${ }^{37}$ Platelet PN-2/APP is also a major protein in platelets accounting for $0.5 \%$ of total platelet protein. ${ }^{37}$ Furthermore, remnant APP mRNA is found in human platelets and some of the full length protein is present in platelet membranes. ${ }^{36}$ Together, these studies clearly indicate that platelets are the major circulating repository for PN-2/APP and provide an effective mechanism for the delivery and expression of large quantities of this protein at specific sites throughout the vasculature.

Investigations by us and others have sought to identify physiologic target proteases that are inhibited by PN-2/APP. Kinetic inhibition studies showed that PN.2/APP is a potent inhibitor of several "trypsin-like" and "chymotrypsin-like" serine proteases including trypsin $\left(K_{\mathrm{i}}=4.2 \times 10^{-10} \mathrm{M}\right)$, chymotrypsin $\left(\mathrm{K}_{\mathrm{i}}=1.6 \times 10^{-9} \mathrm{M}\right)$, epidermal growth factor binding protein $\left(\mathrm{K}_{\mathrm{i}}=5.8 \times 10^{-9} \mathrm{M}\right)$ and the $\gamma$ subunit of nerve growth factor $\left(K_{i}=9.1 \times 10^{-9} \mathrm{M}\right){ }^{14,26,34,38,39}$ More specifically, studies defining the protease inhibitory properties of PN-2/APP revealed that it is a potent inhibitor of coagulation factor $\mathrm{XIa}\left(\mathrm{K}_{\mathrm{i}}=5.5 \times 10^{-11} \mathrm{M}\right){ }^{34,38}$ Factor XIa is the first protease in the intrinsic coagulation pathway whose deficiency leads to bleeding. ${ }^{40}$ The inhibition of factor XIa by PN-2/APP was augmented by heparin suggesting that glycosaminoglycans may play an important role in the regulation of certain physiologic target proteases by PN-2/APP. ${ }^{34,38}$ Together, the findings that platelet PN-2/APP is secreted upon platelet activation along with other $\alpha$ granule constituents and it is a very effective inhibitor of factor XIa, support the notion that PN-2/APP has a physiologic function in regulating hemostasis. ${ }^{33,34,37,38,41}$ Further, its orher protease specificities suggest that it may play a role in regulating other proteolytic events associated with wound repair.

\section{Regulation of Coagulation in the Systemic and Cerebral Vasculature}

Recently, a revised hypothesis on the initiation of blood coagulation was proposed based on studies by Naito and Fujikawa ${ }^{42}$ and Gailani and Broze, ${ }^{43}$ which showed that factor XI, the first committed hemostatic protein, is a better substrate of thrombin than factor XIIa in the presence of a negatively charged surface like dextran sulfate or glycosaminoglycans. In this revised model, coagulation is initiated by generating small amounts of thrombin at the site of injury via the extrinsic pathway (FIG. 2). Thrombin may then serve as the "trigger" to activate factor XI, which initiates the subsequent steps of the intrinsic pathway. Activation of the intrinsic pathway leads to the amplification of thrombin formation, which serves two important functions: (1) sustaining the activation of factor XI by a factor XIIa-independent mechanism, and (2) catalyzing the formation of fibrin leading to clot formation. It is noteworthy that this model implicates thrombin and factor XIa as two key enzymes involved with the amplification system of hemostasis (FIG. 2). 


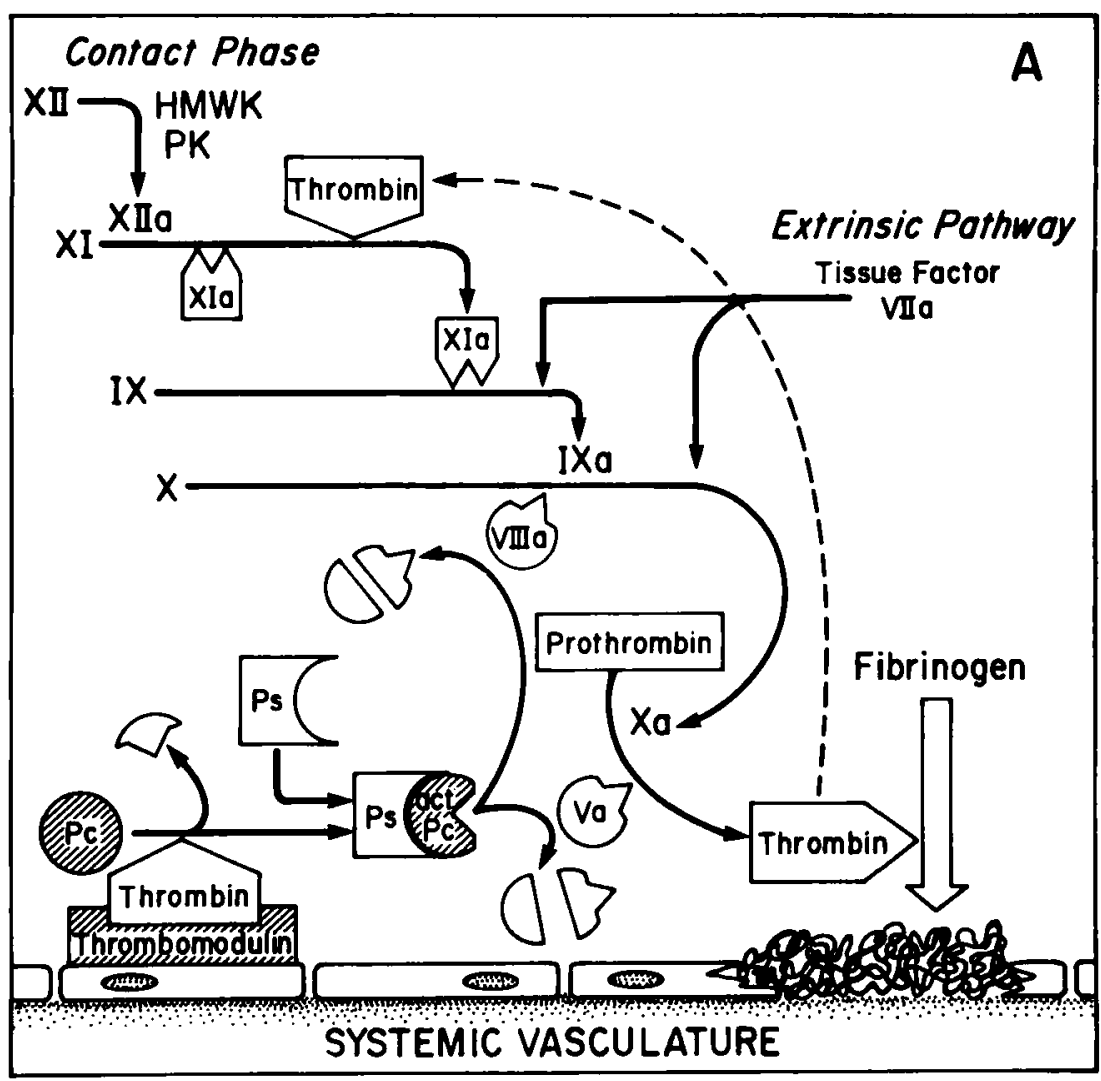

FIGURE 2A. Schematic representation of the regulation of the coagulation cascade in the systemic vasculature. Small amounts of thrombin generated by factor Xa via the extrinsic coagulation pathway can lead to activation of factor XI with subsequent amplification of the intrinsic coagulation pathway. Factor XIa can also autoactivate further contributing to the amplification of the intrinsic pathway. In the systemic vasculature, excess thrombin binds to thrombomodulin and converts protein $\mathrm{C}$ ( $\mathrm{Pc}$ ) into activated protein $\mathrm{C}$ (act. Pc). Optimal activity of Pc requires the presence of Protein S (Ps). Activated Pc-Ps complexes can inactivate coagulation factors Va and VIIIa via proteolysis.

Uncontrolled activation of the coagulation cascade can cause thrombosis leading to stroke and infarct. Systemically, regulation of coagulation is chiefly accomplished by two mechanisms, both of which involve the surface of the vascular endothelium. ${ }^{44}$ The first anticoagulant mechanism is the heparin-antithrombin III system which involves glycosaminoglycans on the surface of the vascular endothelium. The other key anticoagulant molecule distributed on the plasma membrane of arterial, venous, capillary, and lymphatic endothelium is thrombomodulin (Fig. 2A). Thrombomodulin is an integral membrane protein which functions indirectly as an anticoagulant due to its ability to alter the substrate specificity of thrombin. When bound to thrombomodulin, thrombin loses its specificity for fibrinogen and becomes a potent activator 




FIGURE 2B. Schematic representation of the proposed roles of PN-1 and PN-2 in the regulation of the coagulation cascade in the cerebrovasculature. Excess thrombin binds to PN-1 which blocks its ability to cleave fibrinogen or activate factor XI. Excess factor XIa binds to PN-2 which inhibits its ability to activate additional factor $\mathrm{XI}$ and the subsequent steps of the intrinsic coagulation pathway.

of protein C. Protein $\mathrm{C}$ is a serine protease which, in concert with protein $S$, exerts its anticoagulant effect by rapidly hydrolyzing coagulation factors Va and VIIIa. In order for thrombin to effectively activate protein in vivo it must be bound to thrombomodulin.

In the brain, however, thrombomodulin is virtually absent from much of the endothelium of cerebral blood vessels. ${ }^{45}$ This finding suggests that the anticoagulant protein $\mathrm{C}$ system is not operative in the brain. Other regulatory molecules must be present in the brain and the cerebrovasculature to provide a means to control thrombin formation (FIG. 2B). As mentioned above, brain exhibits a very rich and exclusive investment of PN-2/APP, a potent inhibitor of factor XIa. In addition, normal brain, particularly around cerebral blood vessels, is richly invested in $\mathrm{PN}-1$, a potent inhibitor of thrombin. ${ }^{46,47}$ We propose that abundant PN-2/APP and PN-1 working at the level of factor $\mathrm{XIa}$ and thrombin, respectively, could function in concert as major 
intracerebral anticoagulants. Alterations in the levels or functional properties of PN-2/APP and/or PN-1 could lead to coagulation disorders in the brain.

\section{SUMMARY}

The amyloid $\beta$-protein precursor (APP) is the parent molecule to the amyloid $\beta$-protein which is a major constituent of neuritic plaques and cerebrovascular deposits in Alzheimer's disease (AD). The protease inhibitor, protease nexin-2 (PN-2), is the secreted form of APP that contains the Kunitz protease inhibitor (KPI) domain. We reported that the predominant isoform of APP in human brain contains the KPI domain and is thus PN-2. Quantitation of PN-2/APP in various tissues revealed that it is primarily found in brain. Circularing blood platelets are another rich source of PN-2/APP. Platelet PN-2/APP is contained in platelet $\alpha$ granules and is secreted upon activation of platelets by physiological agonists. Protease inhibition measurements demonstrated that PN-2/APP is a potent inhibitor of intrinsic blood coagulation factor XIa. These findings suggest that PN-2/APP may play a role in the regulation of blood coagulation and platelets may serve as a systemic vehicle to deliver large amounts of this protein to sites of vascular injury. In addition, we propose that the rich, and relatively exclusive, investment of PN-2/APP in brain suggests that it may function locally as an intracerebral anticoagulant.

\section{REFERENCES}

1. Glenner, G. G. \& C. W. Wong. 1984. Alzheimer's disease: initial report of the purification and characterization of a novel cerebrovascular amyloid protein. Biochem. Biophy. Res. Commun. 120: 885-890.

2. Glenner, G. G. \& C. W. Wong. 1984. Alzheimer's disease and Down's syndrome sharing of a unique cerebrovascular amyloid protein. Biochem. Biophys. Res. Commun. 122: $1131-1135$.

3. Masters, C. L., G. Multhaup, G. Simms, J. Pottgiesser, R. N. Martins \& K. BEYREUTHER. 1985. Neuronal origin of a cerebral amyloid: neurofibrillary tangles of Alzheimer's disease contain the same protein as the amyloid of plaque cores and blood vessels. EMBO J. 4: 2757-2763.

4. Masters, C. L., G. Simms, N. A. Weinmann, G. Multhaup, B. L. McDonald \& K. BeYreuther. 1985. Amyloid plaque core protein in Alzheimer's disease and Down syndrome. Proc. Natl. Acad. Sci. USA 82: 4245-4249.

5. Masters, C. L. \& K. Beyreuther. 1988. In Aging of the Brain Vol. 32: 183-204. Raven Press. New York.

6. van Duinen, S. G., E. M. Castano, F. Prelli, G. T. A. M. Bots, W. Luyendijk \& B. FRANGIONE. 1987. Hereditary cerebral hemorrhage with amyloidosis in patients of Dutch origin is related to Alzheimer disease. Proc. Natl. Acad. Sci. USA 84: 5991-5994.

7. Kang, J., H.-G. Lemaire, A. Unterbeck, J. M. Salbaum, C. L. Masters, K. H. Grzeschik, G. Multhaud, K. Beyreuther \& B. Muller-Hill. 1987. The precursor of Alzheimer disease amyloid A4 protein resembles a cell surface receptor. Nature 325: 733-736.

8. Goldgaber, D., M. I. Lerman, O. W. McBride, U. Saffiotti \& D. C. Gajdusek. 1987. Characterization and chromosomal localization of a cDNA encoding brain amyloid of Alzheimer's disease. Science 235: 877-880.

9. Tanzi, R. E., J. F. Gusella, P. C. Watkuns, G. A. P. Bruns, P. St. George-Hyslop, M. L. Van Keuren, D. Patterson, S. Pagan, D. M. Kurnit \& R. L. Neve. 1987. Amyloid $\beta$ protein gene: cDNA, mRNA distribution, and genetic linkage near the Alzheimer's locus. Science 235: 880-884. 
10. Robakis, N. K., N. Ramakrishna, G. Wolfe \& H. M. Wisniewski. 1987. Molecular cloning and characterization of a CDNA encoding the cerebrovascular and the neuritic plaque amyloid peptides. Proc. Natl. Acad. Sci. USA 84: 4190-4194.

11. Ponte, P., P. Gonzalez-DeWhitt, J. Schilling, J. Miller, D. Hsu, B. Greenberg, K. Dayis, W. Wallace, I. Lieberburg, F. Fuller \& B. Cordell. 1988. A new A4 amyloid mRNA contains a domain homologous to scrine protease inhibitors. Nature 331: 525-527.

12. Tanzi, R. E., A. I. McClatchey, E. D. Lamperti, L. Villa-Komaroff, J. F. Gusella \& R. L. NeVE. 1988. Protease inhibitor domain encoded by an amyloid protein precursor mRNA associated with Alzheimer's disease. Nature 331: 528-530.

13. Kitaguchi, N., Y. Takahashi, Y. Tokushima, S. Shiojiri \& H. Ito. 1988. Novel precursor of Alzheimer's diseasc amyloid protein shows protease inhibitory activity. $\mathrm{Na}$ ture 331: 530-532.

14. Van Nostrand, W. E., S. L. Wagner, M. Suzukt, B. H. Choi, J. S. Farrow, J. W. Geddes, C. W. Cotman \& D. D. Cunningham. 1989. Protease nexin-II, a potent antichymotrypsin, shows identity to amyloid $\beta$-protein precursor. Nature 341: $546-549$.

15. Oltersdorf, T., L. C. Frutz, D. B. Schenk, I. Lieberburg, K. L. Johnson-Wood, E. C. Beattie, P. J. Ward, R. W. Blacher, H. F. Dovey \& S. Sinha. 1989. The secreted form of the Alzheimer's amyloid precursor protein with the Kunitz domain is protease nexin-II. Nature 341: 144-147.

16. Sisodia, S. S., E. H. Koo, K. Beyreuther, A. Unterbeck \& D. L. Price. 1990. Evidence that $\beta$-amyloid protein in Alzheimer's disease is not derived by normal processing. Science 248: $492-495$.

17. esch, F. S., P. S. Keim, E. C. Beattie, R. W. Blacher, A. R. Culwell, T. Oltersdorf, D. MCClure \& P. J. WARD. 1990 . Cleavage of amyloid to peptide during constitutive processing of its precursor. Science 248: 1122-1124.

18. Wang, R., J. F. Meschia, R. J. Cotter \& S. S. Sisodia. 1991. Secretion of the $\beta /$ A4 amyloid precursor protein. J. Biol. Chem. 266: 16960-16964.

19. Golde, T. E., S. Estus, M. Usiak, L. H. Younkin \& S. G. Younkin. 1990. Expression of $\boldsymbol{\beta}$ amyloid protein precursor $\mathrm{mRNAs}$ : recognition of a novel alternatively spliced form and quantitation in Alzheimer's disease using PCR. Neuron 4: 253-267.

20. Palmert, M. R., M. B. Podlisny, D. S. Witker, T. Oltersdorf, L. H. Younkin, D. J. Selkoe \& S. G. YounKIN. 1988. Antisera to an amino terminal peptide detect the amyloid protein precursor of Alzheimer's disease and recognize senile plaques. Biochem. Biophys. Res. Commun. 156: 432-437.

21. Palmert, M. R., M. B. Podlisny, D. S. Witker, T. Oltersdorf, L. H. Younkin, D. J. SELKOE \& S. G. Younkin. 1989. The $\beta$-amyloid protein precursor of Alzheimer's disease has soluble derivatives found in human brain and cerebrospinal fluid. Proc. Natl. Acad. Sci. USA 86: 6338-6342.

22. Weidemann, A., G. Konig, D. Bunke, P. Fischer, J. M. Salbaum, C. L. Masters \& K. BEYREUTHER. 1989. Identification, biogenesis, and localization of precursors of Alzheimer's disease A4 amyloid protein. Cell 57: 115-126.

23. Van Nostrand, W. E., J. S. Farrow, S. L. Wagner, R. Bhasin, D. Goldgaber, C. W. Cotman \& D. D. Cunningham. 1991. The predominant form of the amyloid $\beta$-protein precursor in human brain is protease nexin-2. Proc. Natl. Acad. Sci. USA 88: 10302-10306.

24. Knauer, D. J. \& D. D. Cunningham. 1982. Epidermal growth factor carrier protein binds to cells via a complex with released carrier protein nexin. Proc. Natl. Acad. Sci. USA 79: $2310-2314$.

25. Knauer, D. J., J. A. Thompson \& D. D. Cunningham. 1983. Protease nexins: cell secreted proteins that mediate the binding, internalization, and degradation of regulatory serine proteases. J. Cell. Physiol. 117: 385-396.

26. Van Nostrand, W. E. \& D. D. Cunningham. 1987. Purification of protease nexin II from human fibroblasts. J. Biol. Chem. 262: 8508-8514.

27. Henrixsson, T., R. M. Barbour, S. Bran, P. Ward, L. C. Fritz, K. Johnson-Wood, H. D. Chung, W. Burke, K. J. Reinikainen, P. Reikkinen \& D. B. Schenk. 1991. Analysis and quantitation of the $\beta$-amyloid precursor protein in the cerebrospinal fluid 
of Alzheimer's disease parients with a monoclonal antibody-based immunoassay. J. Neurochem. 56: 1037-1042.

28. Aral, H., V. M.-Y. Lee, M. L. Messinger, B. D. Greenberg, D. E. Lowery \& J. Q. TROJANOWSKT. 1991. Expression patterns of $\beta$-amyloid precursor ( $\beta$-APP) in neural and nonneural tissues from Alzheimer's disease and control subjects. Ann. Neurol. 30: 686693.

29. Goldgaber, D., H. W. Harris, T. Hla, T. Maciag, J. Donnelly, S. Jacobsen, M. P. VITEK \& D. C. GAJDUSEK. 1989. Interleukin 1 regulates synthesis of amyloid $\beta$-protein precursor mRNA in human endorhelial cells. Proc. Natl. Acad. Sci. USA 86: 76067610.

30. Griffin, W. S. T., L. C. Stanley, C. Ling, L. White, V. Macleod, L. J. Perrot, C. L. White \& C. ARAOz. 1989. Brain interleukin 1 and S-100 immunoreactivity are elevated in Down syndrome and Alzheimer disease. Proc. Natl. Acad. Sci. USA 86: 7611-7615.

31. Tagliavini, F., J. Ghiso, W. F. Timmers, G. Giaccone, O. Bugiani \& B. Frangione. 1990. Coexistence of Alzheimer's amyloid precursor protein and amyloid protein in cerebral vessel walls. Lab. Invest. 62: 761-767.

32. Podlisny, M. B., A. L. Mammen, M. G. Schlossmacher, M. R. Palmert, S. G. Younkin \& D. J. SELKoE. 1990. Detection of soluble forms of the $\beta$-amyloid precursor protein in human plasma. Biochem. Biophys. Res. Commun. 167: 1094-1101.

33. Van Nostrand, W. E., A. H. Schmaier, J. S. Farrow \& D. D. Cunningham. 1990. Protease nexin-II (amyloid $\beta$-protein precursor): a platelet $\alpha$ granule protein. Science 248: 745-748.

34. Smith, R. P., D. A. Higuchi \& G. J. Broze, JR. 1990. Platelet coagulation factor XIainhibitor, a form of Alzheimer amyloid precursor protein. Science 248: 1126-1128.

35. Bush, A. I., R. N. Martins, B. Rumble, R. Moir, S. Fuller, E. Milward, J. Currie, D. Ames, A. Weidemann, P. Fischer, G. Multhaup, K. Beyreuther \& C. L. Masters. 1990. The amyloid precursor protein of Alzheimer's disease is released by human platelets. J. Biol. Chem. 265: 15977-15983.

36. Gardella, J. E., J. Ghiso, G. A. Gorgone, D. Marratta, A. P. Kaplan, B. Frangione \& P. D. GoREVIC. 1990. Intact Alzheimer amyloid precursor protein (APP) is present in platelet membranes and is encoded by platelet mRNA. Biochem. Biophys. Res. Commun. 173: 1292-1298.

37. Van nostrand, W. E., A. H. Schmajer, J. S. Farrow, D. B. Cines \& D. D. CunningHAM. 1991. Protease nexin-2 [amyloid $\beta$-protein precursor] is a platelet-specific protein in blood. Biochem. Biophys. Res. Commun. 175: 15-21.

38. Van Nostrand, W. E., S. L. Wagner, J. S. Farrow \& D. D. Cunningham. 1990. Immunopurification and protease inhibitory properties of protease nexin-2/amyloid $\beta$. protein precursor. J. Biol. Chem. 265: 9591-9594.

39. Sinha, S., H. F. Dovey, P. Seubert, P. J. Ward, R. W. Blacher, M. Blaber, R. A. Bradshaw, M. Arici, W. C. Mobley \& I. Lieberburg. 1990. The protease inhibitory properties of the Alzheimer's $\beta$-amyloid precursor protein. J. Biol. Chem. 265: 89838985.

40. Jackson, C. M. \& Y. Nemerson. 1980. Blood coagulation. Annu. Rev. Biochem. 49: 765-811.

41. Van Nostrand, W. E., A. H. Schmaier, J. S. Farrow \& D. D. Cunningham. 1991. Platelet protease nexin-2/amyloid $\beta$-protein precursor; possible pathologic and physiologic functions. Ann. N.Y. Acad. Sci. 640: 140-144.

42. NAITO, K. \& K. FUjIKaWA. 1991. Activation of human blood coagulation factor XI independent of factor XII. J. Biol. Chem. 266: 7353-7358.

43. Gallani, D. \& G. J. Broze. 1991. Factor XI activation in a revised model of blood coagulation. Science 253: $909-912$.

44. EsMON, C. T. 1987. The regulation of natural anticoagulant pathways. Science 235: 13481352.

45. Maruyama, I., C. E. Bell \& P. W. Majerus. 1985. Thrombomodulin is found on endothelium of arteries, veins, capillaries, and lymphatics, and on syncytiotrophoblast of human placenta. J. Cell. Biol. 101: 363-371. 
46. Wagner, S. L., J. W. Geddes, C. W. Cotman, A. L. Lau, D. Gurwitz, P. J. Isackson \& D. D. Cunningham. 1989. Protease nexin-l, an antithrombin with neurite outgrowth activity, is reduced in Alzheimer disease. Proc. Natl. Acad. Sci. USA 86: 8284-8288.

47. Choi, B. H., M. Suzuka, T. Kim, S. L. Wagner \& D. D. Cunningham. 1990. Protease nexin-l: localization in the human brain suggests a protective role against extravasated serine proteases. Am. J. Pathol. 137: 741-747. 